\title{
Frequently Cited Texts and Abbreviations
}

A G. W. F. Hegel. Hegel's Aesthetics: Lectures on Fine Art. Trans. T. M. Knox. 2 vols. Oxford: Clarendon, 1975.

AW F. W. J. Schelling. The Ages of the World. Trans. F. de Wolfe Bolman. New York: Columbia University Press, 1946.

BL Samuel Taylor Coleridge. Biographia Literaria. Ed. J. Shawcross. 2 vols. London: Oxford University Press, 1907.

CI Søren Kierkegaard. The Concept of Irony. Trans. Lee M. Capel. 1965; rpt. Bloomington: Indiana University Press, 1971.

CUP Søren Kierkegaard. Concluding Unscientific Postscript. Trans. David Swenson and Walter Lowrie. Princeton, N.J.: Princeton University Press, 1941 .

CW William Godwin. Caleb Williams or Things as They Are. Ed. David McCracken. New York: Norton, 1977.

E William Blake. The Complete Poetry and Prose of William Blake. Ed. David V. Erdman, with commentary by Harold Bloom. Rev. ed. Berkeley: University of California Press, 1982. (In citations in the text the abbreviation ' $E$ ' is followed first by the page number; the numbers following the semicolon indicate the plates and lines. Page numbers only are used to cite very brief texts.)

GL Friedrich Schleiermacher. A Critical Essay on the Gospel of Saint Luke. Trans. Connop Thirlwall. London: John Taylor, 1825 .

$H \quad$ Friedrich Schleiermacher. Hermeneutics: The Handwritten Manuscripts. Ed. Heinz Kimmerle. Trans. James Duke and Jack Forstman. Missoula, Mont.: Scholars' Press, 1977.

HK Friedrich Schleiermacher. Hermeneutik und Kritik mit besonderen Beziehung auf das Neue Testament. Ed. Friedrich Lücke (1838). In Sämmtliche Werke, Erste Abtheilung, zweiter Band. Berlin: G. Reimer, 1864 . 
IDP Friedrich Schleiermacher. Schleiermacher's Introductions to the Dialogues of Plato. Trans. William Dobson. Cambridge: J. J. Deighton, 1836 .

$L B \quad$ William Wordsworth and Samuel Taylor Coleridge. Lyrical Ballads: The Text of the 1798 Edition with the Additional 1800 Poems and the Prefaces. Ed. R. L. Brett and A. R. Jones. London: Methuen, 1968. LJ Friedrich Schleiermacher. The Life of Jesus. Ed. Jack Verheyden. Trans. S. Maclean Gilmour. Philadelphia: Fortress Press, 1975.

MWW Mary Wollstonecraft. Mary and The Wrongs of Woman. Ed. James Kinsley and Gary Kelly. Oxford: Oxford University Press, 1980. O Friedrich Schleiermacher. "The Hermeneutics: The Outline of the 1819 Lectures." Trans. Jan Wocjik and Roland Haas. New Literary History 10 (1978): 1-16.

$P \quad$ William Wordsworth. The Prelude 1799, I805, 1850. Ed. Jonathan Wordsworth, M. H. Abrams, and Stephen Gill. New York: Norton, 1979 (quotations from 1850 version).

PM G. W. F. Hegel. The Phenomenology of Mind. Trans. J. B. Baillie. Revised ed., 1931. Rpt. New York: Harper and Row, 1967.

PV $\quad$ S $\varnothing$ ren Kierkegaard. The Point of View for My Work as an Author. Trans. Walter Lowrie. New York: Harper and Row, 1962.

SPP Percy Bysshe Shelley. Shelley's Poetry and Prose. Ed. Donald H. Reiman and Sharon B. Powers. New York: Norton, 1977.

St.L. William Godwin. Travels of St. Leon. London: Henry Colburn and Richard Bentley, 1831.

STC Samuel Taylor Coleridge. The Complete Poetical Works of Samuel Taylor Coleridge. Ed. E. H. Coleridge. 2 vols. Oxford: Clarendon, 1912. 


\section{The Supplement of Reading}


